\title{
The Effect of Leadership Style, Work Environment and Performance Benefits on Employee Performance in BP3TKI Office, Indonesia using Statistical Method
}

\author{
Rizal Saragih $^{1)}{ }^{*}$, Warjio $^{2)}$ \& Susanti1) \\ 1)Public Administration Magister Program, Universitas Terbuka, Indonesia \\ 2)Public Administation Program, Universitas Sumatera Utara, Indonesia
}

Submitted: June, 14 th $^{\text {20 }}$ 202; Reviewed: August, 02 ${ }^{\text {nd }}$ 2021; Accepted: August, $19^{\text {th }} 2021$

*Coresponding Email: rizalsaragih1968@gmail.com

\begin{abstract}
This study aims to determine the effect of leadership style, work environment and performance benefits on employee performance at the Service Office for Placement and Protection of Indonesian Migrant Workers (BP3TKI) Medan. The effect of these variables on employee performance was studied using statistical analysis. The sampling technique used in this study is saturated sampling. Scaled surveys has been done by 116 employees of Service Office for Placement and Protection of Indonesian Migrant Workers (BP3TKI) Medan. The statistical tool used is the Structural Equation Modelling (SEM), and analysed using LISREL 8.80 statistic software. The model developed fulfil Goodness of Fit (GoF) requirements from LISREL 8.80 to which shows that it is good enough. The most significant sub-variables are no strong grip and low confidence from leader, legislations related to employee's performance benefits, and good air circulations in the workspace, which strongly affect work quality, time efficiency, and cooperation from employees in Medan BP3TKI office. For further research, other researchers, institutions, or parties, could use this research conclusion and suggestions as foundation or additional information for similar problems, that is to improve employee performance in an office.
\end{abstract}

Keywords: Employee performance; LISREL 8.80; Structural Equation Modelling.

How to Cite: Saragih, R., Warjio., \& Susanti. (2021). The Effect of Leadership Style, Work Environment and Performance Benefits on Employee Performance in BP3TKI Office, Indonesia using Statistical Method, Journal of Education, Humaniora and Social Sciences (JEHSS), 4(2): 1066-1074 


\section{INTRODUCTION}

The National Agency for the Placement and Protection of Indonesian Workers, or BNP2TKI in Indonesian, is a Non-Ministerial Government Institution in Indonesia. This institution implements policies for field of placement and protection of Indonesian Workers. One of the Technical Implementation Unit of BNP2TKI is the Indonesian Workers Placement and Protection Service Office, or BP3TKI in Indonesian, placed in Medan, North Sumatera Province. This province has a coastline that directly adjacent with Malaysian Peninsular, resulting in a lot of mobility and migration of residents from this province to work in Malaysia under non-procedural regulation. Therefore, it is considered necessary for Medan BP3TKI office to tighten the policies for the placement and protection of Indonesian Workers.

In 2018, Medan BP3TKI office is supported by employees who are central Civil Apparatus (ASN in Indonesian) in the province, which are divided into two statuses, those are 116 employees with the status of Civil Servants (PNS in Indonesian) and 14 employees with the status of Government Employees with Work Agreements (contract workers or honorary workers). In this study, employee performance will be focused on the performance of employees with Civil Servants (PNS) status. To maintain tight policies, it is also considered necessary to maintain work discipline for every employee in the office. However, the level of disciplinary punishment for employees in the office has increased for three years, from 2016 to 2018. This data encourages authors to do research correlated to lower the disciplinary punishment level, in order to tighten the implementation of policies for immigrant workers.

There are several factors that could affect employee performances. The first ones are individual variables, that consists of abilities, skills, background, and demographics. The second factors are psychological variables, that consists of judgements, attitude, personality, motivation, work satisfaction, and work-related stress. The third factors are the organizational factors, which consists of leadership, compensation, conflict, power, organizational structure, job design, organizational culture, and career (Gibson, 2008). In this study, the authors focused on three factors of the organizational factors, that is leadership style, work environment and performance benefits. These three factors are presumed to be strongly connected to employee performance in Medan BP3TKI office.

The first factor, leadership style, is the norm of behaviors used by someone when the person is trying to influence the behaviors of others (Thoha, 2010). Leadership style is a consistent pattern of behaviors that is shown by the leader. These behaviors would be seen by the subordinates when the leader tries to influence them. The problem of leadership style in Medan BP3TKI Office is that there is a mismatch between the expectations of subordinates and the reality of the leadership's attitude. Subordinates want the leader to be soft and democratic, but the leader often being stiff and assertive. The leader's behaviors are presumed to affect employee performance significantly.

The second factor, that is work environment, is a condition, situation, and state of work that could encourage employees to have high enthusiasm and motivation to do their jobs, in order to achieve work productivity (Siswanto, 2000). The work environment is divided into two, the physical and non-physical work environments. The physical work environment is in the form of a building, workspaces, and other work facilities. The non-physical environment is a social environment, that is the social environment between one employee to another. The problem of work environment in Medan BP3TKI Office is the lack of supporting work facilities, workspace is less extensive compared to the number of employees, and the workspace has not been arranged to support the process of placement and protection services for migrant workers. Besides, the office location is quite far, both from the center of Medan city, and from the departure and return point of migrant workers. This makes coordination with other institutions to carry out the placement and protection of migrant workers become difficult. The authors presumed that these reasons would also affect employee performance.

The third factor is the performance benefit. One form of additional compensation is in the form of benefits that aim to make employees "devote their lives" to the office or company in the 
long-term period (Flippo, 1994). The authors would also study the impacts of performance benefit to the employee performance.

The research conducted by Putri, et. al. (2019) explains that work environment influences employee performance and work discipline. Work discipline also mediates the influence of the work environment on employee performance. Demus et al. (2015) research also showed that interpersonal relationship, supervision, training and development, and employee welfare simultaneously influence the employee performance. The data used in these researches were acquired by giving out questionnaire to employees, which the author adapt in this research. However, in this research, author have analyse the correlation between variables using structural equation modelling using LISREL software.

Furthermore, there are other variables that can affect employee performance and work discipline that are not examined. So, the purpose in this research is analyses and prove the effect of leadership style, work environment, and performance benefits on employee performance using both quantitative and qualitative approaches. The parameters used to determine whether these three factors influence employee performance would be statistical parameters used to measure correlations between each variable. This study would also determine which factors affect employee performance the most, and hope that this information would be helpful for Medan BP3TKI office to improve the employee performance and could function better in doing their function.

\section{VARIABLES AND SUB-VARIABLES DETERMINATION}

Before conducting the research, factors that would hypothetically affect employee performance should be determined. As mentioned before, this study would be focused on three main factors, that is leadership style, work environment, and performance benefits. The aim is to improve the employee performance. Hereinafter, these four items (leadership style, work environment, performance benefits, and employee performance) would be referred as variables. Therefore, there are four variables that would be observed. According to previous researches, these factors can be divided into several subfactors, or in this study referred as sub-variables.

There are three leadership styles, those are autocratic, democratic, and freestyle or also known as laissez faire (Indrawijaya, 2006). Based on observations, the authors conclude that the leadership style carried out by the Medan BP3TKI office is the freestyle leadership style, which is characterized by no strong grip and low confidence, and slow in making decisions (Danim, 2004). Thus, for the leadership style factors, the author chose two sub-variables, the first one is no strong grip and low confidence, and the second one is slow in making decisions.

Next, there are several factors (or sub-variables in this research) that could affect the work environment (Nitisemito, 2002), including work relations and communications, spiritual needs, color selection for work facilities, music played during work hours, cleanliness, good air circulations in workspace, secure and calm atmosphere. In Medan BP3TKI office, the author observed that there are three major sub-variables that needs to be improved, the first one is work relations and communications, the second one is good air circulations in workspace, and the last one is secure and calm atmosphere. These three sub-variables were chosen to be the sub-variables of work environment variable.

The next one is sub-variables for performance benefits. There are several factors (or subvariables in this research) that could influence the incentive system (or performance benefit in this research), those are prevailing wages and salaries, demands from labor union, productivity, company policy regarding wages and salaries, and legislation (Siagian, 2008). In another research, sub-variables that could influence the incentive system are employee performance, years of service, seniority, needs, justice and eligibility, and position evaluation. From these sub-variables, authors chose four of them to be observed as sub-variables of performance benefits, those are prevailing wages rate, company policy regarding wages and salaries, legislation, and position evaluation.

\footnotetext{
1. http://mahesainstitute.web.id/ojs2/index.php/jehss

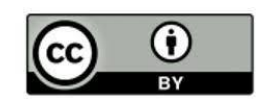


The last one is sub-variables for employee performance. Employee performance affects how much they could contribute to the company, which includes work quantity, work quality, time efficiency, and cooperation (Siswanto, 2012). For employee performance variable, the author chose four sub-variables mentioned, those are work quantity, work quality, time efficiency, and cooperation. The summary of variables and sub-variables observed in this research is shown in table 1 . The first three variables are referred as exogenic latent variables, while employee performance is the endogenic latent variables. The hypothesis of this research is there is significant correlation between three exogenic latent variables and the endogenic latent variables.

Table 1. Variables and sub-variables of this research.

\begin{tabular}{llllc}
\hline \multicolumn{1}{c}{ Type } & \multicolumn{1}{c}{ Variables } & Symbol & \multicolumn{1}{c}{ Sub-variables } & Symbol \\
\hline $\begin{array}{l}\text { Exogenic } \\
\text { latent }\end{array}$ & Leadership style & GAPIM & No strong grip and low confidence & X1 \\
variables & Work & LIKER & Slow in making decisions & X2 \\
& environment & & Gork relations and communications & X3 \\
& & & Secure and calm atmosphere & X4 \\
& Performance & TUKIN & Prevailing wages and salaries & X5 \\
& benefits & & Company policy regarding wages and salaries & X6 \\
& & & Legislation & X8 \\
& & & Position evaluation & X9 \\
Endogenic & Employee & KINER & Work quantity & Y1 \\
latent & performance & & Work quality & Y2 \\
variables & & Time efficiency & Y3 \\
& & & Cooperation & Y4 \\
\hline
\end{tabular}

\section{RESEARCH METHODS}

This research was conducted with both quantitative and qualitative approaches. Quantitative approaches are required to use numbers, starting from data collection, interpretation of the data and results, in addition to quantitative research there is also data in the form of qualitative information, where a qualitative approach is an attempt to obtain clear information on a particular problem in a study (Arikunto, 2006). Meanwhile, combined research methods (mixed methods) is a research method that combines or combines quantitative methods with qualitative methods to be used together in a research activity, in order to obtain more comprehensive, valid, reliable and objective data (Sugiyono, 2010).

This research was conducted at the Medan BP3TKI office, located at Jl. Pendidikan No. 357 Mariendal Village, Medan, North Sumatra, from 30 October to 30 December 2019. The sampling technique used in this study is nonprobability sampling. This sampling technique does not provide equal opportunity for each member of the population to be chosen as the sample. To determine the sample, authors used a saturated sampling technique or census sampling, which means all members of the population are used as samples. This technique is often used if the population is relatively small. As mentioned before, the sampling would be conducted on 116 employees in Medan BP3TKI Office, which held the status of PNS. The quantitative data was collected by questionnaires, while qualitative data was collected by interviews, observations, and documentations for each employee.

Meanwhile, to assess the response of each respondent, this study uses a Likert Measurement Scale (Sugiyono, 2017), which is used to measure attitudes, opinions, and perceptions of a person or group of people about social phenomena. In this research, the social phenomena are the variables and sub-variables mentioned before. The questionnaire contains 2 state of statements, where the first set serve as the indicators for the exogenic latent variables correlation to employee performance (endogenic latent variables). Meanwhile, the second set measure the respondents' individual performance self-review, with statements questioning their views on their own performances, as indicators of employee performance sub-variables. The respondents would answer by giving each statement a score, as shown in table 2 . 
Table 2. Scores given to each answer from the respondents (Sugiyono, 2017).

\begin{tabular}{lc}
\hline \multicolumn{1}{c}{ Statement } & Score \\
\hline Very Agree / Always / Very Positive & 5 \\
Agree / Frequently / Positive & 4 \\
Hesitating / Sometimes / Neutral & 3 \\
Disagree / Almost never / negative & 2 \\
Very Disagree / never & 1 \\
\hline
\end{tabular}

After scoring for each sub-variable are collected, the data would be processed and analyzed with Structural Equation Modelling (SEM) procedure. The first step is to have the data screened through with LISREL 8.80 software, mainly to determine mean value, standard deviation, $t$-value, and frequency of minimum and maximum value of each sub-variable. After each sub-variable score data is screened, Confirmatory Factor Analysis (CFA) of the data would be modelled. There are two stages of CFA. The first stage would give printed output and path diagram of the model as the result. From the first stage of CFA we would be informed the standard loading factors (SLF), standard error, t-value, error variance, validity, and construct reliability (CR) of each sub-variable. The SLF and CR from each sub-variable must be greater than 0.5 (SLF $>0.5, \mathrm{CR}>0.5$ ) for the data to be considered reliable.

After completing firs stage CFA model, the next step is to analyses if the model fulfils Goodness of Fit (GoF) requirements from LISREL 8.80, to determine whether the model is good or fit enough. The requirements specifications will be shown later in data analysis. If the model is good enough, data and model can be analyzed. When analyzing the data, the previous CFA data could be a parameter whether the exogenic and endogenic latent variables are correlated. The correlation would be determined from whether the $t$-arithmetic value from each variable are greater than t-table.

The most significant sub-variables from each exogenic latent variable could be determined by selecting the one with the largest t-value. The second stage CFA would be the structural equations for each variable, which would give information how much each exogenic latent variable affect the endogenic latent variable. The result of this study could later become reference for Medan BP3TKI office to improve the employee performance starting from making changes for the sub-variables which affect employee performance the most.

\section{RESULTS AND DISCUSSION}

The first step is data screening for each sub-variable with LISREL 8.80. The result is shown in table 3. The minimum and maximum possible value is the minimum and maximum score in the questionnaire, thus written 1 and 5.

After data screening, CFA model was constructed. The printed output table of the first stage CFA is shown in table 4 , where the path diagram is shown in figure 1.

Table 3. Data screening for each sub-variable with LISREL 8.80.

\begin{tabular}{|c|c|c|c|c|c|c|c|c|c|}
\hline \multicolumn{10}{|c|}{ Data Screening } \\
\hline Sub-variable & Mean & St. Dev & t-Value & Skewness & Kurtosis & Minimum & Freq. & Maximum & Freq. \\
\hline $\mathrm{X} 1$ & 3.083 & 1.336 & 24.854 & -0.066 & -1.443 & 1.000 & 8 & 5.000 & 11 \\
\hline $\mathrm{X} 2$ & 2.905 & 1.27 & 24.73 & 0.05 & -1.29 & 1.000 & 10 & 5.000 & 6 \\
\hline X3 & 2.84 & 1.28 & 23.90 & 0.14 & -1.42 & 1.000 & 12 & 5.000 & 1 \\
\hline $\mathrm{X} 4$ & 2.86 & 1.26 & 24.49 & 0.21 & -1.26 & 1.000 & 7 & 5.000 & 7 \\
\hline X5 & 2.95 & 1.20 & 26.59 & 0.06 & -1.13 & 1.000 & 8 & 5.000 & 7 \\
\hline X6 & 2.97 & 1.20 & 26.74 & 0.10 & -1.30 & 1.000 & 3 & 5.000 & 4 \\
\hline X7 & 3.05 & 1.19 & 27.55 & 0.00 & -1.24 & 1.000 & 4 & 5.000 & 4 \\
\hline $\mathrm{X} 8$ & 3.03 & 1.25 & 26.19 & 0.05 & -1.06 & 1.000 & 10 & 5.000 & 14 \\
\hline X9 & 3.10 & 1.16 & 28.77 & -0.15 & -1.10 & 1.000 & 5 & 5.000 & 7 \\
\hline Y1 & 2.97 & 1.32 & 24.23 & -0.02 & -1.36 & 1.000 & 13 & 5.000 & 10 \\
\hline Y2 & 3.03 & 1.30 & 25.12 & 0.08 & -1.30 & 1.000 & 8 & 5.000 & 14 \\
\hline Y3 & 3.06 & 1.25 & 26.41 & -0.13 & -1.22 & 1.000 & 9 & 5.000 & 9 \\
\hline Y4 & 3.00 & 1.19 & 27.28 & 0.00 & -1.03 & 1.000 & 8 & 5.000 & 9 \\
\hline
\end{tabular}

10. http://mahesainstitute.web.id/ojs2/index.php/jehss

(1) mahesainstitut@gmail.com

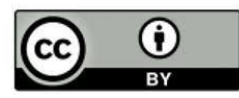


As can be seen on table 4, SLF and CR values of each sub-variables are greater than 0.5 , thus, this model is reliable enough. From the validity column, it is also shown that each sub-variable data is valid, therefore, the analysis can be proceeded into the next step. From the CFA path diagram in figure 1, the value of several statistical parameters can also be obtained, that is Chi-square value of 186.24, degree of freedom of 59, p-value of 0.00000, and RMSEA of 0.137.

Table 4. Printed output table of CFA model.

\begin{tabular}{|c|c|c|c|c|c|c|}
\hline \multicolumn{7}{|c|}{ Confirmatory Factor Analysis (CFA) } \\
\hline $\begin{array}{c}\text { Sub- } \\
\text { variables }\end{array}$ & $\begin{array}{c}\text { St. Loading } \\
\text { Factors (SLF) } \\
>0.5\end{array}$ & $\begin{array}{c}\text { Standard } \\
\text { Error }\end{array}$ & t-Value & $\begin{array}{c}\text { Error } \\
\text { Variance }\end{array}$ & Validity & $\begin{array}{l}\text { Construct } \\
\text { Reliability } \\
\text { (CR) }\end{array}$ \\
\hline $\mathrm{X} 1$ & 1.470 & 0.090 & 16.360 & -0.410 & valid & 1.002 \\
\hline $\mathrm{X} 2$ & 0.890 & 0.100 & 8.650 & 0.800 & valid & 0.996 \\
\hline X3 & 0.730 & 0.120 & 6.140 & 1.100 & valid & 0.994 \\
\hline $\mathrm{X} 4$ & 1.560 & 0.120 & 12.670 & 0.840 & valid & 0.995 \\
\hline $\mathrm{X} 5$ & 0.690 & 0.110 & 6.170 & 0.960 & valid & 0.995 \\
\hline $\mathrm{X} 6$ & 0.640 & 0.099 & 6.520 & 0.770 & valid & 0.996 \\
\hline $\mathrm{X} 7$ & 0.940 & 0.110 & 8.450 & 0.770 & valid & 0.996 \\
\hline X8 & 1.080 & 0.097 & 11.150 & 0.430 & valid & 0.998 \\
\hline X9 & 0.950 & 0.091 & 10.420 & 0.430 & valid & 0.998 \\
\hline Y1 & 1.450 & 0.000 & 0.000 & -0.410 & valid & 1.002 \\
\hline Y2 & 0.960 & 0.091 & 10.640 & 0.760 & valid & 0.996 \\
\hline Y3 & 1.100 & 0.110 & 10.370 & 0.380 & valid & 0.998 \\
\hline Y4 & 0.980 & 0.099 & 9.910 & 0.380 & valid & 0.998 \\
\hline
\end{tabular}

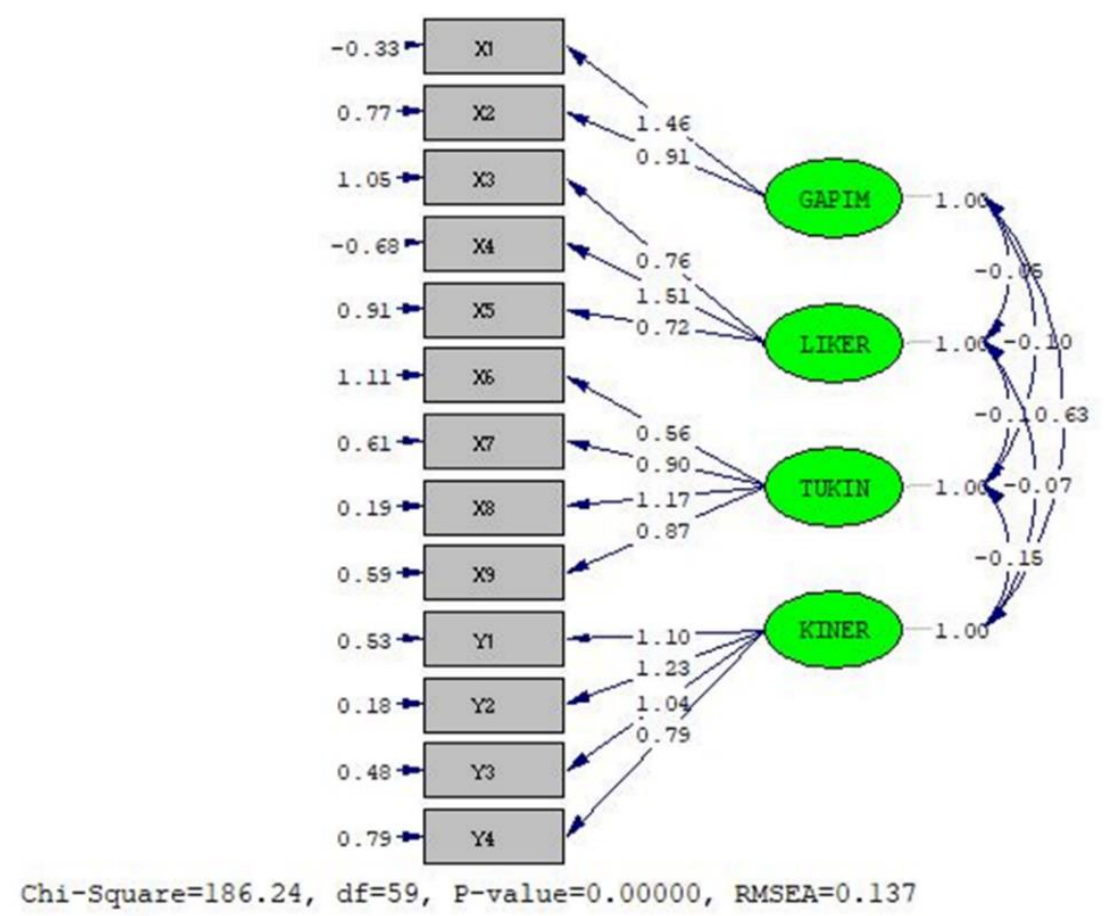

Figure 1. First stage CFA path diagram of model.

The next step is Model Match Test. This step will analyses if the model is fit or good enough by fulfilling the Goodness of Fit (GoF) requirements from LISREL 8.80. The results are shown in table 5. From this table, it is shown that there are 5 Not Fit parameters, 5 Marginal Fit parameters, 
and 5 Good Fit parameters. Therefore, the author concluded that this model is reasonable enough to be proceeded into the next step of data analysis.

Table 5. Result of model analysis with GoF from LISREL 8.80.

\begin{tabular}{|c|c|c|c|c|}
\hline \multirow[b]{2}{*}{ No. } & \multirow[b]{2}{*}{$\begin{array}{l}\text { Goodness of Fit } \\
\text { Index }\end{array}$} & \multicolumn{2}{|c|}{ Overall Model Match Test Results } & \multirow[b]{2}{*}{ Match Level } \\
\hline & & Cut Off Value & Research result & \\
\hline 1 & $\begin{array}{l}\text { Chi-Square } \\
\mathrm{P}\end{array}$ & $\begin{array}{l}\text { Small value } \\
\mathrm{P}>0.05\end{array}$ & $\begin{array}{l}144.97 \\
(P=0.00)\end{array}$ & Not Fit \\
\hline 2 & $\begin{array}{l}\text { NCP } \\
\text { Interval }\end{array}$ & $\begin{array}{l}\text { Small value } \\
\text { Narrow interval }\end{array}$ & $\begin{array}{l}78.48 \\
48.16-116.50\end{array}$ & Marginal Fit \\
\hline 3 & $\begin{array}{l}\text { RMSEA } \\
\text { P (closefit) }\end{array}$ & $\begin{array}{l}\text { RMSEA }<0.08 \\
P>0.05\end{array}$ & $\begin{array}{l}0.11 \\
(P=0.00)\end{array}$ & Not Fit \\
\hline 4 & ECVI & $\begin{array}{l}\text { Small value } \\
\text { Medium value (M) close } \\
\text { with saturated value }(S)\end{array}$ & $\begin{array}{l}M=1.76 \\
S=1.58 \\
I=9.23\end{array}$ & Good Fit \\
\hline 5 & AIC & $\begin{array}{l}\text { Small value } \\
\text { Medium value }(M) \text { close } \\
\text { with saturated value }(S)\end{array}$ & $\begin{array}{l}M=202.48 \\
S=182.00 \\
I=1060.89\end{array}$ & Good Fit \\
\hline 6 & CAIC & $\begin{array}{l}\text { Small value } \\
\text { Medium value (M) close } \\
\text { with saturated value (S) }\end{array}$ & $\begin{array}{l}M=326.34 \\
S=523.58 \\
I=1109.68\end{array}$ & Good Fit \\
\hline 7 & NFI & $\mathrm{NFI}>0.90$ & 0.86 & Marginal Fit \\
\hline 8 & NNFI & $\mathrm{NNFI}>0.90$ & 0.88 & Marginal Fit \\
\hline 9 & CFI & CFI $>0.90$ & 0.91 & Good Fit \\
\hline 10 & IFI & $\mathrm{IFI}>0.90$ & 0.91 & Good Fit \\
\hline 11 & RFI & $\mathrm{RFI}>0.90$ & 0.81 & Not Fit \\
\hline 12 & $\mathrm{CN}$ & $\mathrm{CN}>200$ & 69.18 & Not Fit \\
\hline 13 & RMR (standarized) & $\begin{array}{l}\text { RMR (standarized) } \\
<0.05\end{array}$ & 0.09 & Marginal Fit \\
\hline 14 & GFI & $\mathrm{GFI}>0.90$ & 0.85 & Marginal Fit \\
\hline 15 & AGFI & $\mathrm{AGFI}>0.90$ & 0.76 & Not Fit \\
\hline
\end{tabular}

The results of Structural Equations obtained as follow.

$$
\begin{array}{cccc}
\text { KINER }= & 0.58 * \mathrm{GAPIM}+0.041 * \mathrm{LIKER}+0.049 * \mathrm{TUKIN}, \text { Errorvar }=0.67, \mathrm{R} 2=0.33 \\
(0.068) & (0.048) & (0.032) & (0.12) \\
8.48 & 0.86 & 1.51 & 5.72
\end{array}
$$

From this equation, the table of statistical parameter can be listed in table 6 . The model has degree of freedom of 58 and the value of t-table is 0.67874 . From table 6 it is shown that all variables have $t$-arithmetic value greater than $t$-table value. Thus, it can be concluded that all the variables - those are leadership style, work environment, and performance benefits - give significant influence on employee performance. The highest significant variable is leadership style, with t-arithmetic value 8.48 . The second is performance benefit with a relatively wide gap, with $t-$ arithmetic value 1.51 , followed closely with relatively closer gap by work environment, with tarithmetic value 0.86 . 
Table 6. Statistical parameters of each variable from the modelled structural equation.

\begin{tabular}{cccc}
\hline Variable & Standard Loading Factor & Standard Error & t-arithmetic \\
\hline GAPIM & 0.58 & 0.068 & 8.48 \\
LIKER & 0.041 & 0.048 & 0.86 \\
TUKIN & 0.049 & 0.032 & 1.51 \\
\hline
\end{tabular}

The completed second stage CFA path diagram can be seen in figure 2 . The path diagram is the structural equation model regression results for each variables and sub-variables. From this completed path diagram, it is shown that all three exogenic latent variables (leadership style, work environment, and performance benefits) are significantly correlated with the endogenic latent variables (employee performance). However, we could see that the Y1 sub-variable from employee performance variable (work quantity), is not affected by another variables. The author concluded that work quantity is not affected by leadership style, work environment, nor performance benefits.

From figure 2, it is also shown that the most significant sub-variables from each variable can be determined from the largest t-value. For leadership style variable, the most significant subvariable is $\mathrm{X} 1$, that is no strong grip and low confidence from the leader, with $t$-value 16.36 . For work environment variable, the most significant sub-variable is X4, that is good air circulation in workspace, with t-value 12.67 . For employee benefits, the most significant sub-variable is $\mathrm{X} 8$, that is legislation (related to performance benefits), with t-value 11.15. However, it is followed closely by X9, that is position evaluation, with t-value of 10.42. Lastly, for employee performance variable, the $t$-value of each affected sub-variable (Y2, Y3, and Y4) is relatively close, ranging from 9.91 to 10.64, however the largest t-value is Y2, that is work quality, followed closely by Y3 and Y4, those are time efficiency and cooperation.

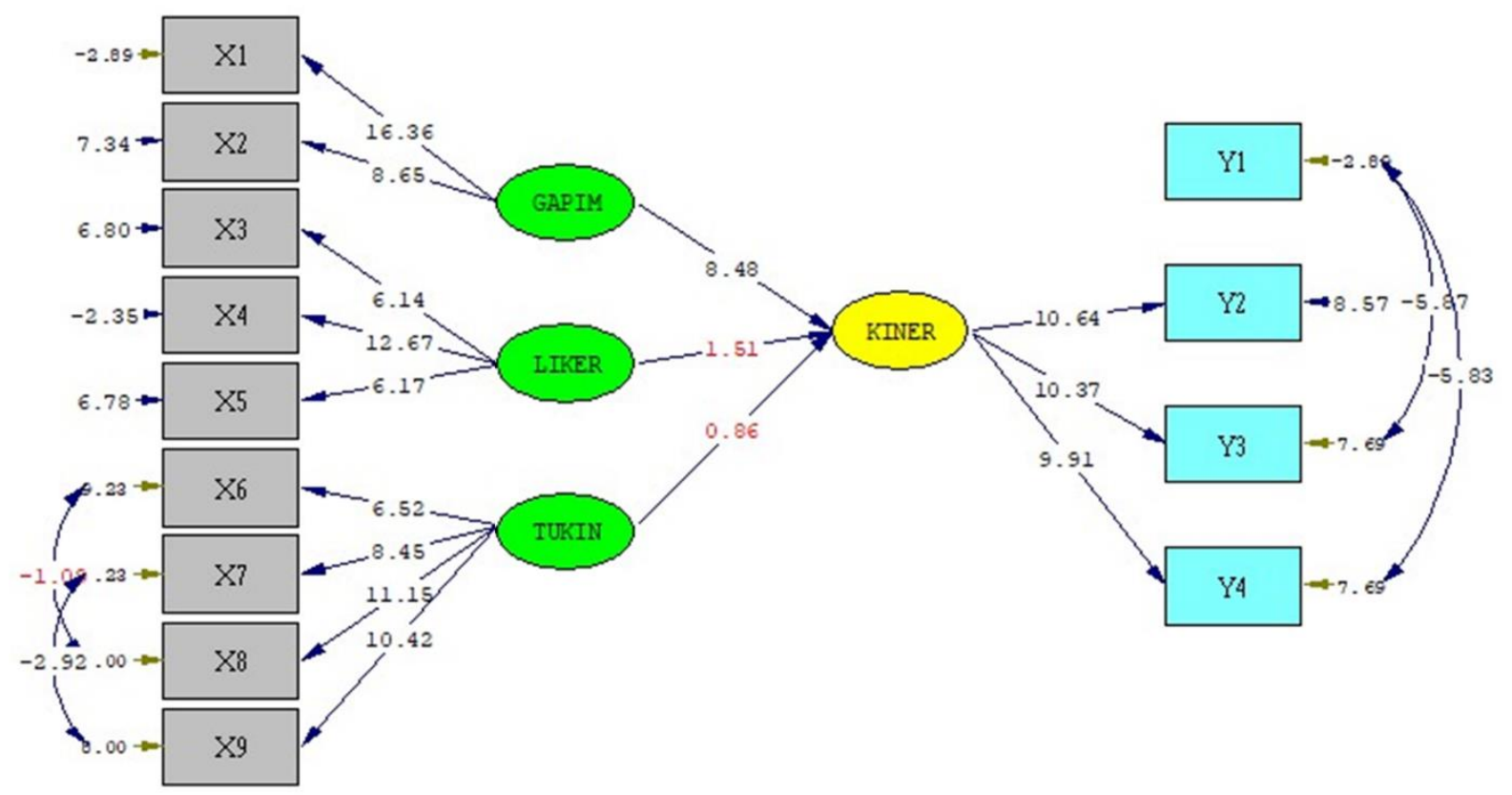

Figure 2. Structural Equation Model Regression Results from second stage CFA.

\section{CONCLUSION}

Based on the research objectives, that is to find the effect of leadership style, work environment, and performance benefits on employee performance in Medan BP3TKI office, several things can be concluded. First, the leadership style has the highest influence on employee performance in Medan BP3TKI office. The highest affecting sub-variable from leadership style is 
no strong grip and low confidence from the leader. This variable and sub-variable would affect employee performance, especially in work quality, time efficiency, and cooperation. Thus, the author suggests the Medan BP3TKI office to improve their leader'sbehaviors on their leadership style, especially encourage the leader to have stronger grip and increase their confidence, in order to improve their employees' work quality, time efficiency, and cooperation.

The second highest influence comes from performance benefits. There are two sub-variables with relatively close influence, those are legislations related to performance benefits and position evaluation. These variable and sub-variables would also affect employee performance, especially in work quality, time efficiency, and cooperation. Thus, the author suggests Medan BP3TKI office to improve their performance benefits policy and legislation, and also improve their employees' position evaluation methods, in order to improve their employee's work quality, time efficiency, and cooperation.

The last one is work environment. In this research it is found that the highest affecting subvariables is good air circulation in the workspace, which would affect the employees' work quality, time efficiency, and cooperation. Thus, the author suggests Medan BP3TKI office to improve the air circulation in the workspace, to give more comfortable working space for their employees, in order to improve their employee's work quality, time efficiency, and cooperation.

All the conclusions above are followed by author's suggestion, in order to improve Medan BP3TKI office employee performance. For further research, other researchers, institutions, or parties, could use this research conclusion and suggestions as foundation or additional information for similar problems, that is to improve employee performance in an office.

\section{REFERENCES}

Arikunto, S. (2010). Prosedur Penelitian Suatu Pendekatan Praktik. Jakarta: Rineka Cipta.

Danim, S. (2004). Motivasi Kepemimpinan dan Efektifitas Kelompok. Jakarta: Rineka Cipta.

Demus, A W., Kindangen, P. \& Tielung, M. V. J. (2015). The Impact of Work Environment on Employee Performance (Case Study at PT. Bank Artha Graha International TBK, Manado Branch Calaca). Jurnal Berkala Ilmiah Efisiensi. 15 (5), 200-210.

Ekowati et. al (2019). The Effect of Work Environment on Employee Performance through Work Discipline. International Journal of Research, 7 (4), 500-510.

Flippo, L. (1994). Karir dalam Organisasi. Terjemahan Susanto Budidharmo. BPFE Universitas Diponegoro. Gibson, I. D. (2008). Organisasi. Jilid I. Edisi 8.Jakarta: Binarupa Aksara.

Handoko, H. T. (2002). Manajemen Personalia dan Sumber Daya Manusia. Yogyakarta: BPFE Liberty.

Hasibuan, H. M. S. P. (2016). Manajemen Sumber Daya Manusia. Jakarta: PT. Bumi Aksara.

Indrawijaya, A. I. (2006). Perilaku Organisasi. Jakarta: PT. Bumi Aksara.

Nitisemito, A. S. (2002). Manajemen Personalia. Edisi 4. Jakarta: Ghaila Indonesia.

Siagian, S. P. (2008). Manajemen Sumber Daya Manusia. Jakarta: PT. Bumi Aksara.

Siswanto. B. (2000). Manajemen Tenaga Kerja. Jakarta: PT. Bumi Aksara.

Siswanto. B. (2012). Manajemen Kerja. Jakarta: PT. Gramedia Pustaka Utama.

Soetopo. H. (2012). Perilaku Organisasi Teori dan Praktek di Bidang Pendidikan. Bandung: PT. Remaja Rosda Karya.

Sugiyono (2017). Metode Penelitian Pendidikan. Bandung: Alfabeta.

Thoha (2010). Kepemimpinan dalam Manajemen. Jakarta: PT. Raja Grafindo Persada.

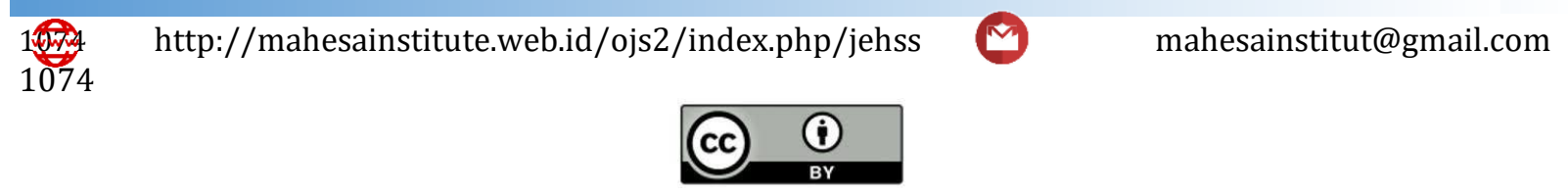

